

ThE WiLliam DAVIDSON INSTITUTE AT THE UNIVERSITY OF MICHIGAN BUSINESS SCHOOL

Does the Balassa-Samuelson Hypothesis Hold for Asian Countries? An Empirical Analysis using Panel Data Cointegration Tests

\author{
By: Imed Drine and Christophe Rault
}

William Davidson Working Paper Number 504

September 2002 


\title{
Does the Balassa-Samuelson hypothesis hold for Asian countries? An empirical analysis using panel data cointegration tests
}

\author{
Imed DRINE; Christophe RAULT ${ }^{\dagger}$ \\ EUREQua, Sorbonne University
}

Septembery 24, 2002

\begin{abstract}
This paper tests empirically the Balassa-Samuelson (BS) hypothesis using annual data for 6 Asian countries. We apply new panel data cointegration techniques recently developed by Pedroni (2000) and we compare the results with those obtained with conventional Johansen (1995)'s time series cointegration tests.

Whereas, standard time series approach turns out to be able to put in evidence a significant long-run relationship between real exchange rate and productivity differential; this relationship is strongly rejected for all countries using recent advances in the econometrics of non-stationary dynamic panel methods. Closer exminations of the three key components of the BS hypothesis enable us to identify clearly the causes of this empirical failure. We find that the absence of a positive long-run relationship between productivity differential and relative prices is the reason for this rejection.
\end{abstract}

Keywords : Real Exchange Rate, Balassa-Samuelson hypothesis, Asian countries, Panel unit-root and cointegration tests.

JEL Classification : E31, F0, F31, C15.

\footnotetext{
*drine@univ-paris1.fr

†chrault@hotmail.com

${ }^{\ddagger}$ Paris I, Maison des Sciences de l'Economie, 106-112 Boulevard de L’Hôpital, 75647 Paris cedex 13 , France.
} 


\section{William Davidson Institute Working Paper 504}

\section{Introduction}

As it is now well-established economists often refer to two alternative theories to explain long-run real exchange rate movements.

The former is Purchasing Power Parity (PPP) according to which real exchange rate must be stationary. This implies there cannot exist persistent deviations from real exchange equilibrium level, but only temporary ones. In this case PPP serves as a good first approximation to long-run behaviour. Recent empirical evidence supporting this proposition under the current float has however been mixed. Parikh and Wakerly (2000) for instance found empirical evidence in favour of this theory, whereas Fleissig and Strauss (2000) rejected it.

The latter, the Balassa-Samuelson (BS) hypothesis, which seeks to explain the persistence of real exchange rate changes, typically focus on the tradebility of goods. According to Balassa (1964) and Samuelson (1964), rapid economic growth is accompanied by real exchange rate appreciation because of differential productivity growth between tradable $(\mathrm{T})$ and nontradable (NT) sectors. Since the differences in productivity increases are expected to be larger in high growth countries, the BS prediction should be more visible among fast growing countries. In this respect, the postwar Japanese record is generally recognized to have been a prime example of the BS hypothesis. 


\section{William Davidson Institute Working Paper 504}

Much attention has been paid in literature to test the validity of this hypothesis using time series econometric techniques. Early cointegration tests such as Engle and Granger (1987) cointegrating regression and Johansen (1988), (1995)) maximum likelihood (ML) procedures produce mixed results. Rogoff (1992), DeLoach (2001), Bahmani -Oskooee (1992), BahmaniOskooee and Rhee (1996) for instance have all investigated whether real exchange rate changes can be explained by relative productivities, but only the latter two managed to put in evidence such a relationship. Using a slightly different approach Asea and Mendoza (1994), De Gregorio and al (1994) find, using annual, sectorial data from OECD countries, that relative prices are explained by relative productivities, but it is unclear whether real exchange rate can be explained by relative productivities. These diverging conclusions may be attributable to the low power of the tests implemented with short spans of data as argued by many researchers, given the fact that we only have less than 25 years of data for the current float.

A possible way of improving the power of these tests is by introducing cross-section variation. This may explain why methods for non-stationary time series panel, including unit root tests (Levin and Lin (1993), Quah (1994), Im, Pesaran and Shin (1997)), and cointegration tests (Pedroni ((1996), (1997), (1999), (2000)) or Blinder, Hsiao and Pesaran (1999)) have been gaining increased acceptance in empirical research. Recent applica- 


\section{William Davidson Institute Working Paper 504}

tions of these panel tests for cointegration include Taylor (1996) to historical episodes of purchasing power parity, Canzoneri and al (1999) (for OECD countries), Drine and Rault (2002a) (for Latin American countries), and Drine et al. (2002b) (For Central and Eastern Europe) to productivity and real exchange rate.

The contribution of this paper is twofold. Firstly, we investigate empirically the "original" BS hypothesis for six Asian countries which doesn't reduce itself to the existence of a positive relationship between the relative prices of NT goods and relative labour productivies as it is sometimes assumed in literature. Indeed, in a very schematic way, the Balassa-Samuelson hypothesis can be decomposed into three main assumptions :

$\left(A_{1}\right)$ the differential of productivities between $\mathrm{T}$ and NT sector and relative prices are positively correlated,

$\left(A_{2}\right)$ real exchange rate and the relative prices of NT goods are positively correlated,

$\left(A_{3}\right)$ purchasing power parity is verified for tradable goods.

A combination of these assumptions causes real exchange rate appreciation. The interest of proceeding similarly is that in case of refuting empirically the BS hypothesis we can identify precisely which of the above assumption (s) is (are) responsible for this rejection.

Secondly, in contrast to previous works that implemented the standard 


\section{William Davidson Institute Working Paper 504}

time series cointegration tests, we employ the most recent development of cointegration techniques in heterogeneous panels developed by Pedroni (2000) and particularly small sample corrections for fully modified parameter estimates, as well as restriction testing on the parameters of cointegrating relationships.

We consider here annual data for 6 Asian economies (India, Indonesia, Korea,the Philippines, Singapore and Thailand) covering the 1983-1997 period, and we compare the panel data econometric results with those that are obtained with conventional unit-root tests and cointegrating techniques. The econometric investigation shows that standard time series cointegration methods support the BS hypothesis, since they turn out to be able to put in evidence a significant long-run relationship between productivity differential and real exchange rate for 5 countries out of 6 . On the contrary, the recent panel cointegration techniques of Pedroni (2000) indicate strong evidence against such a relationship for the six Asian countries. This leads us to examine more precisely the reasons for this failure and to analyze carefully the three key assumptions on which the BS hypothesis rests. This additional step permits us to identify clearly the reason for the BS empirical rejection. Indeed, for all countries we find that this rejection is attributable to the failure of the existence of a significant positive relationship between productivity differential and relative prices (assumption $A_{1}$ ). 


\section{William Davidson Institute Working Paper 504}

The remainder of the paper is organised as follows. In Section 2 we briefly review the Balassa-Samuelson framework. Much attention is paid to make explicit where the three key assumptions of this theory intervene. This enables us to derive formally afterwards the different relationships to be tested in the empirical application. In section 3 we present the panel data unit root tests and panel cointegration methodology that will be used in the empirical application. In section 4 we expose and comment our econometric results for 6 Asian countries. A final section reviews the main findings.

\section{The Balassa-Samuelson hypothesis revisited}

Let us consider a small open economy composed of a set of homogeneous firms. The representative firm produces two goods : a tradable commodity for the world market and a non-tradable one for domestic demand. It is supposed besides that tradable and non-tradable goods production requires both capital and labour. The competition is supposed to be perfect and it ensures that production factors are paid at their marginal productivity; labour factor mobility ensures equal pay. Labour supply is supposed to be constant and all variables are expressed in terms of tradable goods.

As noted by Obstfeld and Rogoff (1996), in the absence of nominal rigidity, equilibrium real exchange rate will only depend on productivity differential. Thus in what follows we present a partial equilibrium model where 


\section{William Davidson Institute Working Paper 504}

the demand side is absent.

\subsection{Firm behaviour}

The representative firm maximises its intertemporal profit expressed in terms of tradable goods under its constraints of technology and capital accumulation, that is :

$$
\begin{gathered}
\left.\operatorname{Max} \int_{0}^{\infty}\left(y_{e}\left(k_{e}, l_{e}\right)+p y_{n}\left(k_{n}, l_{n}\right)-w l-i\right)\right) e^{-r t} d t \\
s c \dot{k}=i-\delta k
\end{gathered}
$$

where,

- $\mathrm{y}_{e}$ denotes the production of tradable goods;

- $\mathrm{y}_{n}$ denotes the production of non-tradable goods;

- $p$ denotes the relative prices of non-tradable goods in terms of tradable ones;

- i denotes investment;

- w denotes wages;

- k denotes capital;

- $\mathrm{r}$ denotes foreign interest rate; 
- $l=l_{n}+l_{e}$ is labour supply.

\subsection{Equilibrium}

The equilibrium is defined as follows

$$
\begin{aligned}
& \frac{\delta y_{e}}{\delta k_{e}}=p \frac{\delta y_{n}}{\delta k_{n}}=r \\
& \frac{p \delta y_{n}}{\delta l_{n}}=\frac{\delta y_{e}}{\delta l_{e}}=w
\end{aligned}
$$

$$
\lambda=1
$$

We thus obtained the following relationship between relative prices and labour productivity ratio :

$$
\frac{\frac{\delta y_{e}}{\delta l_{e}}}{\frac{\delta y_{n}}{\delta l_{n}}}=p
$$

For Cobb-Douglas functions, this relation expresses as :

$$
p=\frac{\alpha \theta_{e}}{\beta \theta_{n}}
$$

, where $\alpha$ and $\beta$ are the production-labour elasticities respectively for tradable and non-tradable sectors and $\theta_{n}, \theta_{e}$ the labour average productions for the two sectors. 


\section{William Davidson Institute Working Paper 504}

Equation (7) indicates that relative prices are a function of the productivity ratio of the two goods. Thus a faster increase of tradable goods productivity than of non-tradable ones leads to an increase in relative prices of non-tradables (Assumption $A_{1}$ ).

Furthermore real exchange rate is defined $a^{1}{ }^{1}$ :

$$
e=\frac{P}{E P^{*}}
$$

where,

E denotes nominal exchange rate,

$\mathrm{P}$ denotes general domestic price index,

$\mathrm{P}^{*}$ denotes general foreign price index.

If we suppose that the consumer's basket contains two commodities, we can express the general price index as :

$$
P=P_{e}^{\epsilon} P_{n}^{1-\epsilon} \text { and } P^{*}=\left(P_{e}^{*}\right)^{\epsilon}\left(P_{n}^{*}\right)^{1-\epsilon}
$$

Then, following Balassa and Samuelson and if we suppose that purchasing power parity in the tradable sector (Assumption 2) is verified, we will have

$$
\log (e)=(1-\epsilon) \log (p)-(1-\epsilon) \log \left(p^{*}\right)
$$

\footnotetext{
${ }^{1}$ Real exchange rate is defined in the following way : an increase implies an appreciation.
} 


\section{William Davidson Institute Working Paper 504}

where,

p denotes relative domestic price for nontradable goods,

$\mathrm{p}^{*}$ denotes relative foreign price for nontradable goods.

According to equation (10) real exchange rate is positively correlated to the relative prices of non-traded goods (Assumption $A_{3}$ ).

Taking the above analysis into account (A1, A2, and A3), we obtain the "general" BS relationship :

$$
\log (e)=\phi+(1-\epsilon)\left[\log \left(\frac{\theta_{e}}{\theta_{n}}\right)-\log \left(\frac{\theta_{e}^{*}}{\theta_{n}^{*}}\right)\right]
$$

This relationship indicates that relative productivity differential determines the long-term real exchange rate behaviour.

\section{Econometric methodology}

We now present the panel unit root tests and panel cointegration tests that we will use in the empirical application reported in section 4 .

\subsection{Panel unit root tests}

Initial methodological work on non-stationary panels focused on testing unit roots in univariate panels. Quah (1994) derived standard normal asymptotic distributions for testing unit roots in homogeneous panels as both time series and cross sectional dimension grow large. Levin and Lin 


\section{William Davidson Institute Working Paper 504}

(1993) derived distributions under more general conditions that allow for heterogeneous fixed effects and time trend. More recently, Im, Pesaran and Shin (1997), studied the small properties of unit root tests in panels with heterogeneous dynamics and proposed alternative tests based on the mean of individual unit-root statistics. In this paper we shall apply Im, Pesaran and Shin (1997) unit-root test (called IPS after) since it is more powerful than those of Quah (1994) and Levin and Lin (1993) used in existing studies.

Levin and Lin's test is considered as more general than those of Quah since it explicitly takes heterogeneity and correlation between units into account. However as shown by Papell (1997) it suffers from size distortion without being able to correct serial correlation adequately. Using Monte Carlo simulations, he showed that the finite sample critical values are greater than those in Levin and Lin (1993). For quarterly data, the critical values are 11\% higher (on average) than those reported by Levin and Lin and for monthly data, they are $3 \%$ higher.

The test proposed by Im, Pesaran and Shin (1997) permits to solve Levin and Lin's serial correlation problem in assuming heterogeneity between units in a dynamic panel framework. Furthermore as shown by Im and al via Monte Carlo simulations it has higher power than that of Levin and Lin. IPS (1997) propose two statistics : a Maximum Likelihood Statistics, called Lbar, and a Student statistic tb. These two statistics are based on individual 


\section{William Davidson Institute Working Paper 504}

Augmented Dickey-Fuller (ADF) regressions. Since an appropriate ADF regression will correct the serial correlation in the data, the IPF panel unitroot test takes care of serial correlation automatically. In our empirical work of section 4 we shall use the tb statistic instead of the Lbar one since IPS's Monte Carlo experiments have shown that it is the more powerful even for a value of $\mathrm{N}$ inferior to 5 . This statistic can be expressed as :

$$
t_{b}=\frac{\sqrt{N}\left(t_{N T}-E\left(t_{T}\right)\right.}{\sqrt{\operatorname{Var}\left(t_{T}\right)}}
$$

where $t_{N T}=\frac{1}{N} \sum_{i=1}^{N} t_{i T}$ is an average of the t individual student statistic in a conventional time series unit-root analysis, $E t_{T}$ and $V\left(t_{T}\right)$ are respectively the mean and variance of $t_{i T}$ under the null hypothesis that the series are integrated of order one with $\mathrm{N} \rightarrow \infty$.

IPS show that under the null hypothesis of non-stationarity, the $t_{b}$ statistic follows the standard normal distribution asymptotically.

\subsection{Panel cointegration tests}

In the empirical application we shall apply Pedroni's cointegration test methodology (1995a, 1997 and 1999) to analyse the Balassa-Samuelson hypothesis. Pedroni (1995a) studied the properties of spurious regressions and tests for cointegration in heterogeneous panels and derived appropriate distributions for these cases. These allow one to test for the presence of long run equilibria in multivariate panels while permitting the dynamic and even 


\section{William Davidson Institute Working Paper 504}

the long run cointegrating vectors to be heterogeneous across individual members. Like the IPS panel unit-root test, the panel cointegration tests proposed by Pedroni also take heterogeneity into account using specific parameters which of course are allowed to vary across individual members of the sample. Pedroni (1997 and 1999) derived the asymptotic distributions and explored the small sample performances of seven different statistics to test panel data cointegration. Of these seven statistics, four are based on pooling along, what is often referred to as the Within dimension (called "panel" after), and the last three ones are based on the Between dimension (called "group" after). These different statistics are based on a model that assumes that cointegration relationships are heterogeneous between individual members and are defined as :

\section{For the Within statistics}

$$
\begin{gathered}
Z_{\rho}^{w}=\left(\sum_{i=1}^{N} \sum_{t=1}^{T} L_{11 i}^{-2} \hat{e}_{i t-1}^{2}\right)^{-1} \sum_{i=1}^{N} \sum_{t=1}^{T} L_{11 i}^{-2}\left(\hat{e}_{i t-1} \Delta \hat{e}_{i t}-\hat{\lambda}_{i}\right): \text { Panel Rho_stat } \\
Z_{t}^{w}=\left(\tilde{s}_{N T}^{* 2} \sum_{i=1}^{N} \sum_{t=1}^{T} L_{11 i}^{-2} \hat{e}_{i t-1}^{* 2}\right)^{-1 / 2} \sum_{i=1}^{N} \sum_{t=1}^{T} L_{11 i}^{-2}\left(\hat{e}_{i t-1}^{*} \Delta \hat{e}_{i t}^{*}\right): \text { Panel Adf_stat } \\
Z_{p p}^{w}=\left(\widetilde{\sigma}^{2} \sum_{i=1}^{N} \sum_{t=1}^{T} L_{11 i}^{-2} \hat{e}_{i t-1}^{2}\right)^{-1 / 2} \sum_{i=1}^{N} \sum_{t=1}^{T} L_{11 i}^{-2}\left(\hat{e}_{i t-1} \Delta \hat{e}_{i t}-\hat{\lambda}_{i}\right): \text { Panel PP_stat } \\
Z_{v}^{w}=\left(\sum_{i=1}^{N} \sum_{t=1}^{T} L_{11 i}^{-2} \hat{e}_{i t-1}^{2}\right)^{-1}: \text { Panel V_stat }
\end{gathered}
$$




\section{For the Between statistics}

$$
\begin{gathered}
Z_{\rho}^{B}=\sum_{i=1}^{N}\left(\sum_{t=1}^{T} \hat{e}_{i, t-1}^{2}\right)^{-1} \sum_{t=1}^{T}\left(\hat{e}_{i t-1} \Delta \hat{e}_{i t}-\hat{\lambda}_{i}\right): \text { Group Rho_stat } \\
Z_{t}^{B}=\sum_{i=1}^{N}\left(\hat{\sigma}_{i}^{2} \sum_{t=1}^{T} \hat{e}_{i, t-1}^{2}\right)^{-1} \sum_{t=1}^{T}\left(\left(\hat{e}_{i t-1} \Delta \hat{e}_{i t}-\hat{\lambda}_{i}\right):\right. \text { Group Adf_stat } \\
Z_{p p}^{B}=\sum_{i=1}^{N}\left(\sum_{t=1}^{T} \hat{s}^{* 2} \hat{e}_{i t-1}^{* 2}\right)^{-1} \sum_{t=1}^{T}\left(\hat{e}_{i t-1}^{*} \Delta \hat{e}_{i t}^{*}\right): \text { Group PP_stat }
\end{gathered}
$$

with,

$\widehat{\lambda}=\frac{1}{T} \sum_{s=1}^{k_{i}}\left(1-\frac{s}{k_{i}+1}\right) \sum_{t=s+1}^{t} \widehat{\mu}_{i t} \widehat{\mu}_{i t-s}$

$\widehat{s}_{i}^{2}=\frac{1}{T} \sum_{t=s+1}^{t} \widehat{\mu}_{i t}^{2}, \widehat{\sigma}^{2}=s_{i}^{2}+2 \widehat{\lambda}_{i}$,

$\widetilde{\sigma}_{i}=\widehat{s}_{i}^{2}+2 \widehat{\lambda}_{i}$,

$\widetilde{\sigma}_{N T}^{2} \frac{1}{T} \sum_{i=1}^{N} \widehat{L}_{11 i}^{-2} \widehat{\sigma}_{i}^{2}$

$\widehat{s}_{i}^{* 2}=\frac{1}{T} \sum_{t=s+1}^{t} \widehat{\mu}_{i t}^{* 2}, \widetilde{s}_{N T}^{* 2}=\frac{1}{T} \sum_{t=s+1}^{t} \widehat{s}_{i t}^{* 2}, \widehat{L}_{11 i}^{2} \sum_{t=1}^{T} \widehat{\eta}_{i t}^{2}+\frac{2}{T} \sum_{s=1}^{k_{i}}\left(1-\frac{s}{k_{i}+1}\right) \sum_{i=1}^{T} \widehat{\eta}_{i t} \widehat{\eta}_{i t-s}$

and where the residuals are extracted from the above regressions :

$$
\begin{aligned}
& \hat{e}_{i t}=\widehat{\rho} \widehat{e}_{i t-1}+\widehat{u}_{i t}, \\
& \hat{e}_{i t}=\widehat{\rho} \widehat{e}_{i t-1}+\sum_{k=1}^{K_{i}} \widehat{\gamma}_{i k} \Delta \widehat{e}_{i t-k}+\widehat{u}_{i t}, \\
& \Delta y_{i t}=\sum_{m=1}^{M} \widehat{b}_{m i} \Delta X_{m i t}+\widehat{\eta}_{i t},
\end{aligned}
$$

Note that in the above writings $L_{i}$ represents the $i^{\text {th }}$ component of the Cholesky decomposition of the residual Variance-Covariance matrix , $\widehat{\lambda}$ and 


\section{William Davidson Institute Working Paper 504}

$\widetilde{\sigma}_{N T}^{2}$ are two parameters used to adjust the autocorrelation in the model, $\sigma_{i}$ and $s_{i}^{2}$ are the contemporaneous and long-run individual variances.

Pedroni has shown that the asymptotic distribution of these seven statistics can be expressed as :

$$
\frac{\chi_{N T}-\mu \sqrt{N}}{\sqrt{v}} \rightarrow N(0,1)
$$

where $\chi_{N T}$ is the statistic under consideration among the seven proposed, $\mathrm{N}$ and $\mathrm{T}$ are the sample parameter values and $\mu$ and $\nu$ are parameters tabulated in Pedroni (1999).

In terms of power Pedroni (1997) showed that for values of T larger than 100, all the proposed seven statistics do fairly well and are quite stable. However for smaller samples ( $\mathrm{T}$ inferior to 20) the Group ADF-Statistic (non-parametric) is the most powerful, followed by the Panel v-Statistic and the Panel rho-Statistic. For this reason, only the group ADF-statistic will be considered in our study for panel cointegration testing. The finite sample distribution for the seven statistics have been tabulated by Pedroni (1997) via Monte Carlo simulations. The calculated test statistics must be larger (in absolute value) than the tabulated critical value to reject the null hypothesis of absence of cointegration. 


\section{Empirical investigation}

\subsection{The data}

We include 6 Asian countries in our sample (India, Indonesia, Korea, the Philippines, Singapore and Thailand). The choice of countries is based on data availability. The empirical period starts in 1983 and ends in 1998, corresponding to 15 observations for the time series dimension. The effective real exchange rate (RER) data are taken from the French database of the CEPII. RER is defined as the ratio between the domestic price index and the foreign price one with respect to the USA multiplied by the nominal exchange rate (so a RER increase indicates an appreciation). The added sectorial value and employement series are taken from the "World Table" of

" the Asian Bank's Key Indicators of Developing Asian and Pacific Countries". The traded sector is composed of the "manufacturing" sector and the "agriculture, hunting, forestry and fishing" sector. The non-traded sector is composed of the service sector (transport, storage and communication, finance, insurance, real estate and business services). The traded price index is the added value deflator of each sector. Average productivities for tradable and non-tradable sectors are defined as the added value devided by employment. 


\section{William Davidson Institute Working Paper 504}

\subsection{Unit-Root test results}

We shall report in this sub-section the results of two kinds of unit-root tests : the conventional time series ones and the Im, Pesaran and Shin (IPS, 1997) panel data ones.

The analysis first step is simply to look at the data univariate properties and to determine their integratedness degree. Theoretically a process is either $\mathrm{I}(0)$, $\mathrm{I}(1)$ or $\mathrm{I}(2)$. Nevertheless in practice many variables or variable combinations are bordeline cases, so that distinguishing between a strongly autoregressive $\mathrm{I}(0)$ or $\mathrm{I}(1)$ process (interest rates are a typical example), between a strongly autoregressive $\mathrm{I}(1)$ or $\mathrm{I}(2)$ process (nominal prices are a typical example) is far from being easy. We have therefore applied a sequence of standard time series unit root tests (Schmidt and Phillips test (1992), Kwiatkowsky, Phillips and Shin test (KPSS) (1992) and the efficient unit-root tests suggested by Elliott, Rothenberg and Stock (1996) (which we shall refer to hereafter as the ERS test)), to investigate which of the $\mathrm{I}(0)$, $\mathrm{I}(1), \mathrm{I}(2)$ assumption is most likely to hold. The results of these conventional unit-root tests are not reported here to save space but they can easily be summarised as follows since clear patterns emerge from them ${ }^{2}$. Indeed, they indicate that the unit-root null hypothesis cannot be rejected at the $5 \%$ level for the three variables under consideration (RER, productivity differential

\footnotetext{
${ }^{2}$ The results of these tests are available upon request.
} 


\section{William Davidson Institute Working Paper 504}

between tradable and non-tradable sectors, relative prices) and for all our Asian countries. We have also applied those three tests on the variables taken in first differences and we find evidence in favour of the rejection of the non-stationary hypothesis for our three series. This leads us to conclude that our series are well characterised as an I(1) process, some with non-zero drift for some countries.

As far as the IPS (1997) panel data unit-root test is concerned (which we have appplied for a model with a constant, and for both a constant and a trend), it indicates that for all 6 Asian countries the unit-root hypothesis cannot be rejected for all series (see table 1 in Appendix).

\subsection{Cointegration test results}

The following panel data formalisation of the Balassa-Samuelson's framework presented in section 2 is fairly straightforward to derive. Indeed, using previous notations the long-run relationship (corresponding to the BS hypothesis) to be tested can be written as :

$$
\log \left(R E R_{i t}\right)=c_{i}+\gamma_{i} \log \left(\frac{\theta_{e i t}}{\theta_{\text {nit }}} / \frac{\theta_{e i t}^{*}}{\theta_{n i t}^{*}}\right)+\varepsilon_{i t}
$$

According to BS predictions, we expect $\gamma_{i}$ to be positive since an increase of real exchange rate implies an appreciation.

In the same way, if empirical evidence doesn’t support the BS hypothesis, the three key assumptions $\left(A_{1}, A_{2}, A_{3}\right)$ to be tested in order to identify the 


\section{William Davidson Institute Working Paper 504}

reason (s) for this rejection write as follows:

$$
\begin{gathered}
A_{1}: \quad \log \left(p_{i t}\right)=c_{1 i}+\gamma_{1 i} \log \left(\theta_{\text {eit }} / \theta_{\text {nit }}\right)+\varepsilon_{1 i t} \\
A_{2}: \quad \log \left(R E R_{i t}\right)=c_{2 i}+\gamma_{2 i} \log \left(p_{i t}\right)+\varepsilon_{2 i t} \\
A_{3}: \quad P_{T}=E P_{T}^{*}
\end{gathered}
$$

The results of the cointegration analysis are reported in Appendix. We consider both time series cointegration tests (see table 2) as well as panel cointegration tests developed by Pedroni (2000) (see table 3), with sample size corrections for small samples like ours. Table 2 reports the results of Johansen's ((1988), (1995)) conventional time series cointegration tests. It appears that for 5 countries out of 6 (India, Indonesia, the Philippines, Singapore and Thailand) the hypothesis of the absence of cointegration between real exchange rate and productivity differential can be rejected at a $5 \%$ level of significance. Thus the findings of cointegration time series tests are consistent with the BS hypothesis.

The implementation of Pedroni's recent panel data cointegration tests (2000) leads to an opposed result since the theoretical long-run relationship 


\section{William Davidson Institute Working Paper 504}

between real exchange rate and productivity differential is now strongly rejected at a $5 \%$ level of significance (see Table 3 ). This result shows the superiority of panel data cointegration tests which are more powerful than conventional time series ones and underlines the necessity to be cautious when interpreting usual time series test results for samples of relatively moderate size. These results suggest that productivity differential doesn't correctly account for long-run real exchange rate movements for our 6 Asian economies. In order to shed some light on the origin of that rejection of the BS hypothesis, our next task is to examine successively each three key component of this hypothesis.

The first key component of the BS hypothesis $\left(A_{1}\right)$ postulates that productivity differential between tradable and non-tradable sectors and relative prices are positively correlated. Empirical evidence from Pedroni's panel cointegration test (2000) reported in Table 3 rejects strongly this assumption at a $5 \%$ level of significance since we were not able to confirm the existence of a significant long-run relationship between these two variables (see Table 3).

Then, we investigate the second key component of the BS hypothesis, that is that real exchange rate and relative prices of non-traded goods are positively correlated. Here we are able to put in evidence a long-run statistical relationship between these two variables for all Asian countries (see 


\section{William Davidson Institute Working Paper 504}

Table 3).

Finally, we test the third key component of the BS hypothesis $\left(A_{3}\right)$ i.e. that PPP holds for tradable goods (which implies that the nominal exchange rates and PPP exchange rates are cointegrated with a cointegrating slope of 1.0). We investigate using a t-test if the slope in the cointegrating relationship is equal to 1 , as predicted by Balassa-Samuelson. To get robust results and avoid well-known small sample problems, we estimate our long-run parameters using small sample corrections recently proposed by Pedroni (2000). The empirical results (reported in Table 4) do support this unitary theoretical relationship which is accepted by data at a $5 \%$ level of significance, the fully modified OLS slope estimates being only of 0.74 with a T-Ratio of 1.66 for the null hypothesis that $\beta_{1 i}=1.0$. This finding is in accordance with the acceptance of the second component tested previously.

Thus, the main conclusion which emerges from the above analysis is that the failure of the BS hypothesis for the countries can be attributed to the rejection of the first key component of this hypothesis. Indeed, empirical evidence clearly indicates that productivity differential between tradable and non-tradable sectors and relative prices are not cointegrated. 


\section{William Davidson Institute Working Paper 504}

\section{Conclusion}

So, do Pedroni's recent cointegration techniques (2000) which enable to deal with non-stationary data in heterogeneous panels, as well as with small sample size, permit to rescue the Balassa-Samuelson hypothesis?

The evidence from a panel of 6 Asian countries reveals that these new methods do much better than usual time series cointegration ones (see Johansen (1988), (1995)), since unlike the latter, they indicate the absence of a significant cointegrating relationship between real exchange rate and productivity differential.

One possible reason is that the main assumptions that comprise the BS hypothesis are not verified. Thus, questioning for the reasons of this failure led us to examine separately the validity of each of the three key components of the BS hypothesis. This empirical analysis is rich of teachings and allows us to clearly identify why this theory is not confirmed for all Asian economies. We find that the rejection of the BS hypothesis can be accounted for by the rejection of the expected positive long-run relationship between relative prices of non-traded goods and productivity differential. A possible explanation of the BS empirical rejection may simply be that there are additional long-run real exchange determinants that have to be considered. 
William Davidson Institute Working Paper 504

\section{Aknowledgements}

We would like to thank Peter Pedroni for providing us with some RATS codes for the computation of the critical values, making the panel cointegration tests available in this present analysis, as well as for his modified group-fm program for small sample adjustments. 


\section{William Davidson Institute Working Paper 504}

\section{References}

[1] Asea, P.K., Mendoza E. (1994), "The Balassa-Samuelson Model : A General Equilibrium Appraisal", Review of International Economics vol 2, pp :244-67.

[2] Bahmani-Oskooee, M., "A Time-Series Approach to Test the Productivity Bias hypothesis in Purchasing Power Parity", Kyklos, vol 45, pp $227-36$.

[3] Bahmani-Oskooee, M., Rhee J.H, "Time-Series Support for Balassa's Productivity-Bias Hypothesis: Evidence from Korea", Review of International Economics, vol 4, pp 364-370.

[4] Balassa, B.(1964), "The purchasing Power Parity doctrine : A reappraisal“", The Journal of Political Economy, Vol. 72: 584-596.

[5] Balassa, B. (1973), "Just how misleading are official exchange rate conversions : A comment", Economic Journal, Vol. 83: 1258-1267.

[6] Blinder M., Hsiao C., Peaseran M.H (1999), " Likelihood based inference for panel vector autoregressions : testing for unit roots and cointegration in short panels", dowloadable at http://www.econ.cam.uk/faculty/pesaran. 


\section{William Davidson Institute Working Paper 504}

[7] Canzoneri M., Cumby R., Diba B. (1999), " Relative labor productivity and the real exchange rate in the long run : evidence for a panel of OECD countries", Journal of International Economics, vol 47, pp 245266.

[8] Cottani, J.A., Cavallo, F. and Khan Shahbaz (1990), "Real Exchange Rate Behavior and Economic Performance in LDCs", Economic Development and Cultural Change, Vol.39:61-76.

[9] De Gregorio J., Giovannini A., Wolf H.C (1994), "International Evidence on Tradables and Non-Tradables Inflation", European Economic Journal, vol 38, pp 1225-1244.

[10] DeLoach S.B (2001), "More evidence in favour of the Balassa-Samuelson hypothesis", Review of International Economics, vol 9, pp 336-341.

[11] Drine I. and Rault C. (2002a), "Do Panel Data permits to rescue the Balassa-Samuelson Hypothesis for Latin American Countries," Applied Economics, (forthcoming).

[12] Drine, I., Égert B., Lommatzsch K. and Rault C. (2002b), "The Balassa-Samuelson effect in Central and Eastern Europe: Myth or reality ?", William Davidson Institute Working Paper Series, 2002, n 483 , University of Michigan Business School, USA. To be revised for Journal of Comparative Economics. 


\section{William Davidson Institute Working Paper 504}

[13] Elliott G., Rothenberg T.H, Stock J.H (1996), "Efficient tests for an autoregressive unit root", Econometrica, vol 64, pp 813-836.

[14] Engle, R. and Granger, C. (1987), "Cointegration and Error Correction : Representation, Estimation, and Testing" Econometrica, Vol. 55 : $257-76$.

[15] Engel, C. (1995), "Accounting for US real exchange rate changes", NBER working paper, no. 5394.

[16] Fleissig, A. and Strauss, J. (2000), "Panel unit root tests of purchasing power parity for price indices" Journal of International Money and Fiance, Vol. 19 : 489-506.

[17] Im K., Pesaran H., Shin Y. (1997), "Testing for unit roots in heterogeneous panels", Discussion Paper, University of Cambridge, June.

[18] Ito T., Isard P., and Symansky S. (1997), "Economic growth and real exchange rate : an Overview of the Balassa-Samuelson hypothesis in Asia”, NBER Working Paper 5979.

[19] Johansen S. (1988), "Statistical analysis of cointegration vectors", Journal of Economic Dynamics and Control, vol 12, pp 231-254. 


\section{William Davidson Institute Working Paper 504}

[20] Johansen, S. (1995), "Likelihood-Based Inferences in Cointegration Vector Autoregressive Models", Advanced Texts in Econometrics, 267p. Oxford and New York : Oxford University Press.

[21] Kwiatowski, Phillips, Schmidt \& Shin (1992), "Testing the Null Hypothesis of Stationarity Against the Alternative of a Unit Root: How Sure Are We That Economic Time Series Have a Unit Root?", Journal of Econometrics, Vol. 54: 159-178.

[22] Levin and Lin (1993), "Unit root tests in panel data, asymptotic and finite sample properties", U.C. San Diego Working paper.

[23] Obstfeld M., Taylor A (1996), "International capital-market integration over the long run : the great depression as a watershed", manuscript, U.C. Berkeley.

[24] Obstfeld, K. and Rogoff, P. (1996), "Foundation of International Macroeconomics". Cambridge, Mass : Mit Press.

[25] Pappell, D. and Cluver, S. (1997), " Is there a Unit Root in the Inflation Rate? Evidence from Sequential Break and Panel Data Models" Journal of Applied Econometrics, Vol. 12 : 435-44.

[26] Parikh, A. and Walkerly, E. (2000), "Real Exchange Rates and Unit Root Tests" Weltwirtchaftliches Archiv, Vol. vol 136 (3) : 478-490. 


\section{William Davidson Institute Working Paper 504}

[27] Pedroni, P. (1996), "Fully modified OLS for heterogeneous cointegrated panels and the case of Purchasing Power Parity", Indiana University Working Paper in Economics, no. 96-020. June.

[28] Pedroni, P.(1997), "Panel cointegration : asymptotic and finite sample properties of pooled time series tests with an application to the PPP hypothesis : New results", Indiana University Working Paper in Economics, April.

[29] Pedroni, P. (1999), "Critical values for cointegrating tests in heterogeneous panels with multiple regressors", Oxford Bulletin of Economics and Statistics.

[30] Pedroni, P. (2000) "Fully Modified OLS for Heterogeneous Cointegrated Panels," Advances in Econometrics, Vol. 15, forthcoming.

[31] Quah D. (1994), "Exploiting Cross Section variations for unit root inference in dynamic data", Economics Letters, n44, pp 9-19.

[32] Roldos, J. E. (1995), "Supply-Side Effects of Disinflation programs" IMF Working Paper, WP/94/84.

[33] Rogoff, K., "Traded Goods Consumption Smoothing and the Random Walk Behavior of the Real Exchange Rate", Bank of Japan Monetary and Economic Studies, vol 10, pp 1-29. 
William Davidson Institute Working Paper 504

[34] Samuelson, P.A., "Theoretical Notes on Trade Problems", Review of Economics and Statistics, vol 46, pp 335-46.

[35] Taylor (1996), " International capital mobility in history : purchasing power parity in the long-run", manuscript, Northwestern University. 
Appendix : Unit-root and cointegration test results for 6 Asian Countries

Table I. Panel Unit Root tests (ADF test statistics)

(Im, Pesaran and Shin (1997))

\begin{tabular}{|c|c|c|c|c|}
\hline \multirow[t]{4}{*}{ Real exchange rate } & \multicolumn{3}{|c|}{ Ln (TCR) } & \\
\hline & \multicolumn{2}{|l|}{ Level } & \multicolumn{2}{|c|}{ First difference } \\
\hline & Constant $^{\top}$ & Constant and trend ${ }^{2}$ & Constant & Constant and trend \\
\hline & -1.44 & $-0,19$ & $-44,09$ & $-62,20$ \\
\hline \multirow[t]{4}{*}{ Productivity } & differential & $\operatorname{Ln}(P m n)$ & & \\
\hline & Level & & irst differenc & \\
\hline & Constant & Constant and trend & Constant & Constant and trend \\
\hline & $-1,37$ & 1,07 & $-56,69$ & $-66,68$ \\
\hline \multirow[t]{4}{*}{ Relative Prices } & & In (Ptn) & & \\
\hline & Level & & irst differenc & \\
\hline & Constant & Constant and trend & Constant & Constant and trend \\
\hline & $-1,27$ & $-1,43$ & $-26,45$ & $-34,28$ \\
\hline
\end{tabular}

Table II. Conventional cointegration tests (Johansen (1995))

Test of the Balassa-Samuleson hypothesis i.e the existence of a long-run relationship between Real exchange rate and Productivity differential

\begin{tabular}{|c|c|c|c|c|c|}
\hline & L_max & & Trace & & $\begin{array}{l}\text { Number of } \\
\text { cointegrating }\end{array}$ \\
\hline $\mathrm{HO}$ & 0 & 1 & 0 & 1 & relationships \\
\hline India & $14.571^{3}$ & $3.321^{4}$ & $17.89^{5}$ & $3.321^{6}$ & 1 \\
\hline Indonesia & 14.341 & 3.711 & 17.051 & 3.711 & 1 \\
\hline Korea, & 6.106 & 0.570 & 6.677 & 0.570 & 0 \\
\hline The Philippines & 16.581 & 3.257 & 16.841 & 3.257 & 1 \\
\hline Singapore & 15.322 & 3.719 & 15.541 & 3.719 & 1 \\
\hline Thailand & 17.106 & 3.570 & 6.677 & 3.570 & 1 \\
\hline
\end{tabular}

\footnotetext{
${ }^{1}$ The critical value at a $5 \%$ level is -1.65 .

${ }^{2}$ The critical value at a $5 \%$ level is -1.65 .

${ }^{3}$ The critical value at a $10 \%$ level is 14.1 .

${ }^{4}$ The critical value at a $10 \%$ level is 3.8 .

${ }^{5}$ The critical value at a $10 \%$ level is 15.4 .

${ }^{6}$ The critical value at a $10 \%$ level is 3.8 .
} 
Table III : Panel Cointegration tests (Pedroni $(1996,2000))^{7}$

\begin{tabular}{|l|c|c|c||}
\hline Test statistics & $\begin{array}{c}\text { 6 countries, 2 variables } \\
\text { In (TCR), In (Pmn) }\end{array}$ & $\begin{array}{c}\mathbf{6} \text { countries, 2 variables } \\
\text { In (Ptn), In (Pmn) }\end{array}$ & $\begin{array}{c}\mathbf{6} \text { countries, 2 variables } \\
\text { In (TCR), In (Ptn) }\end{array}$ \\
\hline panel v-stat & 1.22294 & 0.55707 & -0.77056 \\
panel rho-stat & -0.3084 & -0.35934 & 1.26434 \\
panel pp-stat & -0.92083 & -1.35555 & 1.38549 \\
panel adf-stat & -1.05016 & -1.23938 & 1.78278 \\
\hline group rho-stat & 0.16321 & 0.76197 & 1.84372 \\
group pp-stat & -0.90071 & -0.78468 & 1.60162 \\
group adf-stat & $\mathbf{- 0 . 6 2 5 8}$ & $\mathbf{- 0 . 6 4 5 1 7}$ & $\mathbf{1 . 7 8 7 8 8}$ \\
\hline
\end{tabular}

Note : In the Pedroni-Rats code a value of 2 is chosen for the m lag option, but the conclusions concerning the acceptance/ rejection of the null hypothesis of no cointegration are not sensitive to the value of the lag truncation $(m$ lag $=1,2,3)$.

Table IV. Panel test for PPP in tradable sector for 6 Asian countries_Pedroni (2000)

\begin{tabular}{|c|c|c|}
\hline & $\begin{array}{l}\text { Cointegrating } \\
\text { coefficient }\end{array}$ & t-stat \\
\hline India & 0.69 & -1.38 \\
\hline Indonesia & 0.98 & -0.15 \\
\hline Korea & 1.68 & -1.59 \\
\hline The Philippines & 0.86 & -2.35 \\
\hline Singapore & 0.99 & -1.60 \\
\hline Thailand & 0.62 & -1.38 \\
\hline Average Coefficient & 0.74 & $1.66^{9}$ \\
\hline
\end{tabular}

\footnotetext{
${ }^{7}$ It is important here to stress that the rejection of the panel null hypothesis of no cointegration for a set of countries means that there exist a cointegrating relationship for each country of the panel (cf. Pedroni). Let us give a simple example to illustrate this.

Imagine that each member of the panel represents a draw from an underlying population. The panel in this case simply represents a repeated sampling, $\mathrm{N}$ times, from an underlying population. In this case, the population DGP either is cointegrated or is not cointegrated. As you increase the number of individuals of the panel, you are simply accumulating information regarding whether or not the population DGP is cointegrated or is not cointegrated. In this case, the proper interpretation of the panel test is :

Null hypothesis: The DGP is not cointegrated, Alternative hypothesis : The DGP is cointegrated

This translates, for the panel, into the statement : Null hypothesis : No individuals are cointegrated, Alternative hypothesis : All individuals are cointegrated. Under this interpretation, there is no such thing as one individual being cointegrated and the others not being cointegrated. The appearance of possible contradictions based on individual tests is simply a consequence of sampling error in the estimator, not differences in the truth regarding cointegration.

This interpretation is useful in practice when you have a theory that says, if the theory is correct as a general description of the way the world works, then two variables should be cointegrated, regardless of which country the variables come from.

${ }^{8}$ Pedroni (1996 and 2000) derived the asymptotic distributions and explored the small sample performances of seven different statistics to test cointegration on panel data. Of these seven statistics, four are based on pooling along, what is often referred to as the Within dimension and the last three ones are based on the Between dimension. These different statistics are based on a model that assumes that cointegration relationships are heterogeneous between individual members (See Pedroni for further details).

The critical value at a $5 \%$ level is -1.65 . The calculated test statistics must be larger (in absolute) value than the tabulated critical value to reject the null hypothesis of absence of cointegration.

${ }^{9} \mathrm{~T}$-stats are for the null hypothesis that the estimated coefficient is equal to 1.
} 


\section{DAVIDSON INSTITUTE WORKING PAPER SERIES - Most Recent Papers}

The entire Working Paper Series may be downloaded free of charge at: www.wdi.bus.umich.edu

CURRENT AS OF 9/30/02

\begin{tabular}{|c|c|c|}
\hline Publication & Authors & Date \\
\hline $\begin{array}{l}\text { No. 504: Does the Balassa-Samuelson Hypothesis Hold for Asian } \\
\text { Countries? An Empirical Analysis using Panel Data Cointegration Tests }\end{array}$ & Imed Drine and Christophe Rault & Sep. 2002 \\
\hline No. 503: Job Growth in Early Transition: Comparing Two Paths & $\begin{array}{l}\text { Štěpán Jurajda and Katherine } \\
\text { Terrell }\end{array}$ & Aug. 2002 \\
\hline $\begin{array}{l}\text { No. 502: Job Creation, Destruction and Transition in Poland, 1988- } \\
\text { 1998: Panel Evidence }\end{array}$ & $\begin{array}{l}\text { John E. Jackson and Bogdan } \\
\text { Mach }\end{array}$ & June 2002 \\
\hline $\begin{array}{l}\text { No. 501: Competition, Innovation and Growth in Transition: Exploring } \\
\text { the Interactions between Policies }\end{array}$ & $\begin{array}{l}\text { Philippe Aghion, Wendy Carlin } \\
\text { and Mark Schaffer }\end{array}$ & Mar. 2002 \\
\hline No. 500: Women in the LAC Labor Market: The Remarkable 1990's & $\begin{array}{l}\text { Suzanne Duryea, Alejandra Cox } \\
\text { Edwards and Manuelita Ureta }\end{array}$ & June 2001 \\
\hline $\begin{array}{l}\text { No. 499: Human Capital, Growth and Inequality in Transition } \\
\text { Economies }\end{array}$ & Michael Spagat & July 2002 \\
\hline No. 498: Understanding Czech Long-Term Unemployment & $\begin{array}{l}\text { Štěpán Jurajda and Daniel } \\
\text { Münich }\end{array}$ & Aug. 2002 \\
\hline $\begin{array}{l}\text { No. 497: Rent Seeking and Government Ownership of Firms: An } \\
\text { Application to China's Township-Village Enterprises }\end{array}$ & Jiahua Che & Sep. 2002 \\
\hline No. 496: Labor Market Flexibility in Central and East Europe & Jan Svejnar & Aug. 2002 \\
\hline $\begin{array}{l}\text { No. 495: When Information Dominates Comparison: A Panel Data } \\
\text { Analysis Using Russian Subjective Data }\end{array}$ & Claudia Senik & May 2002 \\
\hline No. 494: Corruption and Cross-Border Investment: Firm Level Evidence & $\begin{array}{l}\text { Beata K. Smarzynska } \\
\text { Jin Wei }\end{array}$ & Aug. 2002 \\
\hline $\begin{array}{l}\text { No. 493: Modeling Sequences of Long Memory Positive Weakly } \\
\text { Stationary Random Variables }\end{array}$ & Dmitri Koulikov & Aug. 2002 \\
\hline $\begin{array}{l}\text { No. 492: Effects of Ownership and Financial Status on Corporate } \\
\text { Environmental Performance }\end{array}$ & $\begin{array}{l}\text { Dietrich Earnhart and Lubomír } \\
\text { Lízal }\end{array}$ & Aug. 2002 \\
\hline $\begin{array}{l}\text { No. 491: Does Economic Uncertainty Have an Impact on Decisions to } \\
\text { Bear Children? Evidence from Eastern Germany }\end{array}$ & $\begin{array}{l}\text { Sumon Kumar Bhaumik and } \\
\text { Jeffrey B. Nugent }\end{array}$ & July 2002 \\
\hline $\begin{array}{l}\text { No. 490: The Reallocation of Workers and Jobs in Russian Industry: } \\
\text { New Evidence on Measures and Determinants }\end{array}$ & J. David Brown and John S. Earle & Aug. 2002 \\
\hline $\begin{array}{l}\text { No. 489: The Incidence and Cost of Job Loss in a Transition Economy: } \\
\text { Displaced Workers in Estonia, 1989-1999 }\end{array}$ & $\begin{array}{l}\text { Hartmut Lehmann, Kaia Phillips } \\
\text { and Jonathan Wadsworth }\end{array}$ & Aug. 2002 \\
\hline No. 488: Integration: An Empirical Assessment of Russia & $\begin{array}{l}\text { Daniel Berkowitz and David N. } \\
\text { DeJong }\end{array}$ & Feb. 2002 \\
\hline $\begin{array}{l}\text { No. 487: Dual Inflation under the Currency Board: The challenges of } \\
\text { Bulgarian EU accession }\end{array}$ & $\begin{array}{l}\text { Nikolay Nenovsky and Kalina } \\
\text { Dimitrova }\end{array}$ & July 2002 \\
\hline $\begin{array}{l}\text { No. 486: Worker Flows, Job Flows and Firm Wage Policies: } \\
\text { An Analysis of Slovenia }\end{array}$ & $\begin{array}{l}\text { John Haltiwanger and Milan } \\
\text { Vodopivec }\end{array}$ & July 2002 \\
\hline $\begin{array}{l}\text { No. 485: Do Schumpeterian Waves of Creative Destruction Lead to } \\
\text { Higher Productivity? Panel Data Evidence from Poland }\end{array}$ & Frederic Warzynski & July 2002 \\
\hline $\begin{array}{l}\text { No. 484: Labor Market Institutions and Restructuring: Evidence from } \\
\text { Regulated and Unregulated Labor Markets in Brazil }\end{array}$ & Jasper Hoek & July 2002 \\
\hline $\begin{array}{l}\text { No. 483: The Balassa-Samuelson effect in Central and Eastern Europe: } \\
\text { Myth or reality? }\end{array}$ & $\begin{array}{l}\text { Balázs Égert, Imed Drine, Kirsten } \\
\text { Lommatzsch and Christophe } \\
\text { Rault }\end{array}$ & July 2002 \\
\hline No. 482: Real Exchange Rates in Transition Economies & Boštjan Jazbec & July 2002 \\
\hline $\begin{array}{l}\text { No. 481: Labor Force Participation Dynamics in the Romanian Labor } \\
\text { Market }\end{array}$ & Alexandru Voicu & July 2002 \\
\hline $\begin{array}{l}\text { No. 480: Equilibrium Real Exchange Rates in Central Europe's } \\
\text { Transition Economies: Knocking on Heaven's Door }\end{array}$ & Balázs Égert & July 2002 \\
\hline $\begin{array}{l}\text { No. 479: The Impact of Minimum Wages on Wage Inequality and } \\
\text { Employment in the Formal and Informal Sector in Costa Rica }\end{array}$ & $\begin{array}{l}\text { Fatma El-Hamidi and Katherine } \\
\text { Terrell }\end{array}$ & Apr. 2001 \\
\hline
\end{tabular}

